\title{
Kısmi Süreli İşlerin Kalitesi: Çoklu Doğrusal Regresyon Modeli ile OECD Ülkelerinden Bulgular
}

\author{
Ayhan GÖRMÜŞ*
}

öz

1970'den beri birçok gelişmiş ülkede giderek artış gösteren kısmi süreli istihdam, son zamanlarda düşük iş kalitesi ile gündeme gelmektedir. Çalışanların mutluluğuna katkıda bulunan ve doğası gereği çok boyutlu bir yapıyı temsil eden iş kalitesini ölçmek için farklı göstergeler kullanılmaktadır. Bu göstergeler arasında, örneğin OECD İş Kalitesi Çerçevesi kazanç kalitesi, işgücü piyasası güvencesi ve çalışma ortamının kalitesi olmak üzere üç temel boyutta yapılandırılmıştır. Bu açıdan, bu çalışma temel olarak, OECD ülkelerinin verilerini kullanarak, korelasyon ve çoklu doğrusal regresyon analizi yöntemleri ile kısmi süreli istihdam hacmi ile iş kalitesi göstergeleri arasındaki iliş̧iyi incelemeyi amaçlamaktadır. Ampirik sonuçlar, daha yüksek kısmi süreli istihdam oranlarının, daha iyi iş kalitesiyle ilişkili olduğunu göstermektedir. Bu ilişki, kısmi süreli istihdam oranlarının gelişmiş OECD ülkelerinde daha yüksek, gelişmekte olan OECD ülkelerinde ise, daha düşük olmasının bir sonucudur. Ayrıca regresyon analizi; kazanç kalitesi, eğitim ve öğrenme ile kariyer ilerleme firsatındaki artışın ve fiziksel sağlık risk faktörlerindeki azalmanın, kısmi süreli istihdam hacmini farklı derecelerde artırabileceğini ortaya koymaktadır.

Anahtar Kelimeler: Kısmi süreli istihdam, İş hacmi, İş kalitesi, OECD ülkeleri

JEL Sınıflandırması: J21, J31 J41, J81

\section{The Quality of Part-time Jobs: Findings from OECD Countries for Multiple Linear Regression Model}

\begin{abstract}
Part-time employment, which has been increasing in many developed countries since 1970, has recently become a current issue with low job quality. Different indicators have been used to measure job quality that contributes to the well-being of employees and inherently represents by a multidimensional structure. Among these indicators, for instance, OECD Job Quality Framework is structured in three main dimensions: earning quality, labour market insecurity and quality of the work environment. In this line, this study mainly aims to examine the relationship between the quantity of part-time employment and job quality indicators by correlation and multiple linear regression analysis methods, by using data from OECD countries. Empirical results display that higher part-time employment rates are related to better job quality. This relationship is a result that part-time employment rates are higher in developed OECD countries while being lower in developing OECD countries. Also, regression analysis reveals that the increase in earning quality, training and learning and opportunity of career advancement as well as the reduction in physical health risk factors may increase the quantity of part-time employment at varying degrees.
\end{abstract}

Keywords: Part-time employment, Quantity of jobs, Job quality, OECD countries

JEL Classification: J21, J31 J41, J81

Geliş Tarihi / Received: 13.04.2021 Kabul Tarihi / Accepted: 06.06.2021 Doi: 10.17541/optimum.915213

\footnotetext{
* Doç. Dr., Tekirdağ Namık Kemal Üniversitesi, İ̈BF, Çalışma Ekonomisi ve Endüstri Bölümü, agormus@ nku.edu.tr, ORCID: 0000-0002-6175-5381.
} 


\section{GİRIŞ}

1970'lerden itibaren küreselleşme ile rekabetin uluslararası alana taşınması ve teknolojik ilerlemelerle birlikte, bir taraftan artan işsizlik baskısı, diğer taraftan istihdam yoğunluğunun hizmetler sektörüne kayması, istihdamın yapısını daha esnek hale getirmiş ve kısmi süreli istihdam gibi, a-tipik istihdam biçimleri giderek yaygınlık kazanmaya başlamıştır (Görmüş, 2019: 1006). Bu anlamda birçok gelişmiş ülkede çalışma ilişkilerinin normatif temelinde tam zamanlı standart çalışma düzenlemelerinden uzaklaşılırken, kısmi süreli istihdam gibi standart dış1 çalışma düzenlemelerinde bir artış olmuştur. Çalışma iliş̧ilerinin doğasındaki bu değişim, işgücü piyasalarını ve işletmeleri daha esnek hale getirmiş (Kalleberg, 2006: 562) ve kısmi süreli istihdama yönelik gerek ulusal gerekse uluslararası düzeyde tanımlamalar yapılmıştır. Örneğin, Uluslararası Çalışma Örgütü'nün (ILO) 175 Sayılı Kısmi Süreli Çalışma Sözleşmesi’nde, kısmi süreli çalışma, "normal çalışma sürelerinden az; sürekli, düzenli ve gönüllü olarak yapılan çalışma" olarak tanımlanmakla birlikte, bu çalışma biçimini tanımlayan çalışma süresi eşiği ülkelere göre farkl1lık göstermektedir (Fagan vd., 2014: 4). Kısmi süreli çalışma Amerika Birleşik Devletleri'nde (ABD) haftada 35 saatten az, Almanya'da ise, 36 saatten daha az çalışma biçimi olarak tanımlanırken, Kanada ve Birleşik Krallık'ta, kesme noktası olarak haftalık 30 saat kullanılmaktadır. Fransa'da ise, yasal çalışma sürelerinin en az \%20'sinden daha az çalışma, kısmi süreli çalışma olarak kabul edilmektedir. Diğer taraftan, Birleşik Krallık'taki “sıfır saatlik sözleşme" (zero-hour contract) veya işçilerin günde birkaç saatlik iş için istihdam edildiği Fransa, İtalya ve İspanya'daki "röle sözleşmeleri" (relay contracts) dahil olmak üzere, çeşitli kısa süreli çalışma biçimleri de bulunmaktadır. Bunun dışında, Japonya'daki kısmi süreli çalışma, çalışılan saatlerle değil, firma içindeki statüyle ilişkilidir. Bazı Japon araştırmaları, işverenleri tarafindan kısmi süreli olarak sınıflandırılanların \%20-30'unun aslında tam zamanlı çalışanlar kadar uzun sürelerle çalıştığını göstermektedir (Kalleberg, 2006: 567). Türkiye'de ise, normal çalışma süresinin 2/3'ünden daha az süreli, yani haftalık çalışma süresi 30 saatin altında çalışanlar, kısmi süreli çalışan olarak kabul edilmektedir.

Kısmi süreli istihdam düzenlemeleri açısından hükümetler ve sosyal ortaklar arasında, önemli yaklaşım farklılıkları bulunmaktadır. Özellikle Kuzey Avrupa'da işgücü piyasası esnekliğine yönelik daha geniş bir politik tercihin bir parçası olarak kısmi süreli istihdam, kadınların işgücü piyasasına girişini desteklemek ve çalışanların ücretli çalışma sorumlulukları ile aile sorumluluklarını dengelemelerine olanak sağlamak için hükümet politikaları ile açıkça teşvik edilmiştir (ILO, 2016: 75). Sosyal ortaklar ise, kısmi süreli istihdamın teşviki açısından daha pasif kalmayı veya direnç göstermeyi tercih etmektedirler. Ancak 1990'ların başından beri uluslararası düzeyde çabalar değiş̧en olmakla birlikte, Ekonomik Kalkınma ve İşbirliği Örgütü (OECD) ülkelerinin çoğunu genel olarak, yüksek kaliteli kısmi süreli istihdamı teşvik eden ve gönülsüz kısmi süreli istihdamı azaltan bir takım yasal reformlar yapmıştır (Fagan vd., 2014: 41). Bu bağlamda, kısmi süreli istihdamın önemi, birçok gelişmiş ülkede giderek artış göstermiştir. Çalışanlar açısından kısmi süreli istihdam, çoğunlukla iş hayatı ile aile sorumluluklarını veya eğitim ve öğretim ya da kısmi emekliliği bütünleştirmeyi kolaylaştırarak, özellikle kadınlar, öğrenciler ve yaşlı çalışanlar gibi, istihdamında zorluk çekilen grupların istihdama katılmalarına ya da istihdamda kalmalarına imkân sağlarken, bazı çalışan grupları için kısmi süreli çalışma kararı, dar bir alternatif kümesi içinde tek uygun seçenek olabilmektedir. Bu açıdan, çocuk ve yaşı bakım hizmetlerindeki eksiklikler nedeniyle birçok kadın kısmi süreli işlere kanalize edilmektedir (Fagan vd., 2014: 41; ILO, 2016: 75). Diğer taraftan kısmi süreli istihdam, işverenler açısından, operasyonel esneklik sağlamaya yönelik optimum işgücüyle çalışma veya daha düşük saatlik ücretlerle çalış1labilecek işler yaratarak, saatlik işgücü maliyetlerini düşürme yönüyle oldukça cazip ve faydalı bir çalışma biçimidir (Fagan vd., 2014: 42). Bazen de şirketler, kısmi süreli istihdamı emeklilik yaşı gelmiş yaşlı çalışanları işte tutmak ya da vasıflı çalışanları ve belirli programlar veya zor işler için çalışanları çekmek ya da elde (işte) tutmak için kullanmaktadır (ILO, 2016: 75). Şirketler için bu avantajlar, 2009'daki küresel 
ekonomik krizin ardından çok daha geçerli hale gelmiştir. Çünkü çalışma sürelerinin azalması, işverenlerin işgücü düzeylerini korumasına imkân sağlarken, aynı zamanda işgücü maliyetlerini de düşürmüştür (Fagan vd., 2014: 42).

Olumlu sayılabilecek bazı yönlerine rağmen, kısmi süreli istihdam ile artan esnekliğin çalışanlar açısından karanlık bir tarafı da bulunmaktadır. Bu istihdam biçimi, bazen daha büyük işgücü piyasası eşitsizliklerine yol açarken, bazı çalışanları standart istihdam ilişkisinde önceden kendilerine sunulan bazı sosyal korumalardan dışlamaktadır (Kalleberg, 2006: 562). Bununla birlikte, kısmi süreli işlerde çalışanların, tam zamanlı çalışanlara göre, daha kötü çalışma koşullarında, düşük vasıflı işlerde yoğunlaştığı ve kısmi süreli işlerin, tam zamanlı işlere kıyasla, önemli ölçüde daha düşük kalitede olduğu da kabul edilmektedir. Bu açıdan kısmi süreli işler, benzer tam zamanlı işlere göre, daha düşük ücret, sınırlı mesleki gelişme, eğitime katılma ve kariyer firsatları ile ilişkilendirilmektedir. Bu yönleriyle kısmi süreli işler düşük kaliteli istihdam fırsatları sunduğu için sürekli bir eleştiri odağı olmaktadır (Warren ve Lyonette, 2015: 62; OECD, 2010: 221; Fagan vd., 2014: 41). Gerçekten de kısmi süreli iş firsatları, profesyonel ve yönetim pozisyonlarında nispeten daha azdır ve genellikle daha düşük dereceli pozisyonlarla sınırlandırılmıştır (Fagan vd., 2014: 4). Bu listeye yüksek iş güvencesizliği ve düşük sendikal yoğunluk da ilave edilmelidir (OECD, 2010: 221). Kısmi süreli istihdamın bu yönleri Atkinson'un (1987) "çekirdek" ve "çevre" işgücü yaklaşımıyla da oldukça uyumludur. Atkinson (1987), çekirdek işgücünün tam zamanlı çalışanların, çevre işgücünün ise, kısmi süreli çalışanların egemenliğinde olduğunu ileri sürmektedir. Bu açıdan, kısmi süreli işlerde kadın yoğunluğu geleneksel olarak, erkeklere göre, daha yüksek olduğu için kadın çalışanların ve özellikle kadın kısmi süreli çalışanların ikincil ve çevresel işgücü piyasalarında aşırı yoğunlaştı̆̆ ve hatta sıkışıp kaldığı ileri sürülmektedir (Warren ve Lyonette, 2015: 62-64).

Kısmi süreli istihdamla ilgili bir başka sorun da, çalışma süresi tercihleri ve bu tercihlere uygun işlerin mevcudiyeti arasındaki işgücü piyasası uyumsuzluğundan kaynaklanmaktadır. Bu nedenle, gönüllü ve gönülsüz kısmi süreli istihdam (bkz. Görmüş ve Erdoğan, 2017) arasında bir ayrım yapılmaktadır (Bardasi ve Gornick, 2002: 8; Caputo ve Cianni, 2001: 313). Gönüllü olanlar, tam zamanlı çalışmak yerine, kısmi süreli çalışmaya karar vermiş çalışanları ifade ediyorken, gönülsüz olanlar tam zamanlı işlerde çalışmak istemesine rağmen, tam zamanlı iş açığı nedeniyle gönülsüz kısmi süreli işlerde çalışmak zorunda kalanları ifade etmektedir. $\mathrm{Bu}$ açıdan, k1smi süreli istihdamın önündeki en önemli engel, gelirdeki düşüşün pek çok hanehalkı için kolay bir şekilde telafi edilememesidir (Fagan vd., 2014: 41). 2009'daki küresel ekonomik krizin de etkisiyle, artan işsizlik baskısı nedeniyle gönülsüz kısmi süreli istihdam oranı da, başta $A B D$ ve Birleşik Krallık olmak üzere, $O E C D$ ve Avrupa Birliği (AB) ülkelerinde önemli ölçüde artış göstermiştir (Görmüş ve Erdoğan, 2017: 153).

Türkiye'de kısmi süreli çalışmayı iş ve sosyal güvenlik hukuku boyutuyla değerlendiren birtakım çalışmaların (Görgücü ve Koç, 2011; Zeytinoğlu, 2011; Mutlu, 2013; Yuyucu, 2017) yanı sıra, kısmi süreli çalışmanın sosyo-ekonomik ve demografik faktörlerini ampirik olarak inceleyen bazı çalışmalardan (Güneş ve Acun, 2015; Görmüş ve Erdoğan, 2017; Yalçın ve Başol, 2020) oluşan bir literatür birikmesine rağmen, kısmi süreli işlerin kalitesiyle ilgili çalışmaların eksikliği göze çarpmaktadır. Türkiye'de kayıtlı kısmi süreli istihdam oranı gelișmiş OECD ülkelerinden oldukça düşük olmakla birlikte, y1llar içerisinde ciddi bir gelişim gösterememiştir. $\mathrm{Bu}$ anlamda OECD verilerine göre, 1990 yılında \%2,66 olarak hesaplanan istihdam oranı içindeki kısmi süreli çalışan oranı, küçük bir artışla 2019'da \%2,92'ye yükselebilmiştir. $\mathrm{Bu}$ açıdan 2019 yılı kısmi süreli istihdam oranı, toplam istihdamın yalnızca \%6,39'unu oluşturmaktadır. Ancak bu oran Türkiye'deki kısmi süreli istihdamın sadece resmi boyutunu yansıtmaktadır. Yani, Türkiye'deki istihdamın \%30'dan fazlasının kayıt dışı olduğu ve kayıt dışı istihdamın önemli bir kısmının kısmi süreli çalışanlardan oluştuğu düşünüldüğünde, bu oranın sadece buzdağının görünen yüzünü yansıttığı kabul edilmelidir. Bu yönüyle kadın istihdamı üzerinde olumlu etkileri olduğu bilinen kısmi süreli istihdamın iş kalitesinin 
araştırılması ve tartışılması oldukça önemli ve değerlidir. Bu alandaki literatüre katkı sağlamak ve Türkiye için dersler çıkarmak amacıyla yapılan bu çalışmada, şu sorulara cevap aranacaktır: İş kalitesi geçmişten günümüze hangi göstergeler ile ölçülmektedir? İş kalitesi göstergeleri ile kısmi süreli istihdam hacmi arasında nasıl bir korelasyon bulunmaktadır? Hangi iş kalitesi göstergeleri, kısmi süreli istihdam hacmini anlamlı olarak açıklayabilmektedir? Bu sorular ve daha fazlasına cevap vermek için bu çalışma temel olarak, OECD ülkelerinin iş kalitesi verilerini kullanarak, bağımlı çalışanlar arasında kısmi süreli istihdam hacmi ile iş kalitesi göstergeleri arasındaki ilişkiyi korelasyon ve çoklu doğrusal regresyon analiz yöntemleriyle incelemeyi amaçlamaktadır. Bu amaca yönelik, çalışmanın bundan sonraki kısımları, "işs kalitesinin ölçümü", "kismi süreli istihdam hacmi ve iş kalitesi arasındaki ilişki", "yöntem" ve son olarak elde edilen sonuçların tartışıldığ "sonuç" bölümlerinden oluşmaktadır.

\section{2. İS KALITESINIIN ÖLÇÜMÜ}

Çalışma ekonomisi literatüründe, iş kalitesi, geleneksel olarak ücret seviyesiyle temsil edilirken, bazı sosyolojik veya endüstri ilişkileri çalışmalarında çalışma koşullarıyla ilişkilendirilmektedir. Ancak ekonomi ve sosyo-ekonomik yaklaşımlardaki son gelişmeler, iş kalitesi tanımına yeni ek boyutlar kazandırmıştır. Bu anlamda, beşerî sermaye teorisindeki gelişmeler, hem işlerin, hem de çalışanların heterojenliğini kabul etmekle birlikte, belirli işleri içeren becerilere ya da çalışanlar ve işler arasındaki beceri uyumuna göre iş kalitesini ayrıştırmaktadır. $\mathrm{Bu}$ yaklaşıma göre, makro düzeyde piyasa başarısızlıkları beșerî sermaye yatırımını düşürebilir. Bu yüzden, eğitim ve öğretim faaliyetlerine katılım ve yatırım, istihdam kalitesinin bir göstergesi olarak kabul edilebilir (Erhel ve Guergoat-Larivière, 2010: 1).

Ekonomi, sosyoloji ve psikoloji literatürü, iş kalitesinin çalışanların psikolojik, sosyal ve ekonomik mutluluğu (well-being) üzerinde derin sonuçları olduğunu göstermektedir. Bu açıdan sosyal bilimciler, iş kalitesi araştırmalarına farklı şekillerde yaklaşmaktadırlar. Örneğin, ekonomistler, ücretler veya sağlık sigortası ya da emeklilik yardımları gibi, ekonomik konulara odaklanma eğilimindedir. Sosyologlar ise, genellikle bir sosyal tabakalaşma sistemi içinde mesleki prestijin yanı sıra, çalışanların işleri üzerindeki kontrol ve özerklik derecesini incelerken, psikologlar daha çok işin özündeki anlamlı ve zorlayıcı işler gibi, işin ekonomik olmayan yönlerini vurgulamakta ve iş memnuniyetinin psikolojik kaynaklarının çeşitliliğini değerlendirmektedirler. Aslında bu perspektiflerin her biri faydalıdır, ancak iş kalitesini kısmen açıklayabilmektedir. $\mathrm{Bu}$ yüzden iş kalitesini anlamak, işlerin kalitesine ilişkin ekonomik ve ekonomik olmayan unsurları göz önünde bulunduran çok boyutlu bir yaklaşım gerektirmekte ve iş kalitesinin bu bileşenlerinin tümü, önemli araştırma odakları oluşturmaktadır (Kalleberg ve Vaisey, 2005: 431-432).

Çoğu insan zamanının önemli bir kısmını işte harcamakta ve hayatlarının önemli bir bölümünü çalışarak geçirmektedir. Bu nedenle insanların sahip oldukları işler, çalışanların mutluluk ve refahına katkıda bulunan iş kalitesini ifade eden, çok boyutlu bir kavramdır (OECD, 2016: 1). Bu açıdan son zamanlarda iş kalitesinin ölçülmesinde hem nesnel, hem de öznel yaklaşımların birleştirilmesi giderek daha yaygın hale gelmiştir. Bu anlamda literatürde kısmen, yaşam memnuniyeti ve mutluluk gibi sübjektif iyi oluş durumu ölçümleri giderek daha fazla kullanılmaya başlanmıştır. İş memnuniyeti gibi sübjektif ölçütleri de ölçüme dahil etmek, daha geleneksel bir fayda kavramının yanı sıra, ücretler ve çalışma süreleri gibi, objektif ölçütler kullanmaya kıyasla, iş kalitesi ve işyerindeki mutlulukla ilgili büyük resmi göstermektedir (Kauhanen ve Nätti, 2015: 786; Erhel ve Guergoat-Larivière, 2010: 1). Bu anlamda iş kalitesinin çok boyutlu doğasını hesaba katarak, beceriler, çalışma çabası ve yoğunlaştırma, çalışanların takdir yetkisi, ücretler, risk ve iş güvencesizliği ve çalışanların refahı dahil iş kalitesinin çok boyutlu karakterini inceleyen Green'e (2006) göre, çalışma yaşamı veya iş kalitesi, çalışan mutluluğunu artıran bir dizi iş özelliğinden oluşmaktadır. Bu nedenle, iş yerinde mutluluk, iş 
kalitesi kavramı ve ilgili literatürle yakından ilgilidir. Ancak, Kauhanen ve Nätti'nin (2015) çalışması, iş kalitesinin ve çalışma koşullarının çalışanların mutluluğu üzerinde büyük bir etkisi bulunmadığı sonucuna ulaşmıştır.

İş kalitesinin nasıl ölçüleceği noktasında da tam bir görüş birliği bulunmamakla birlikte, uluslararası örgütlerin iş kalitesine ilişkin değişik yaklaşımlar geliştirdiği görülmektedir. Örneğin Uluslararası Çalışma Örgütü'nün (ILO) ilk kez 1999'daki 87. Uluslararası Çalışma Konferansı'nda ortaya attığı "insana yakışır iş kavramı" (decent work), iş kalitesinin değerlendirilmesiyle ilgili olarak işçi haklarının geliştirilmesi, istihdam, sosyal koruma ve sosyal diyalog olmak üzere dört hedeften bahsetmiştir. ILO'nun insana yakışır iş hedefinde sadece daha fazla yeni iş değil, aynı zamanda kabul edilebilir kalitede işlerin yaratılması amaçlanarak, iş hacmi iş kalitesinden ayrı tutulmamıştır (ILO, 1999: 3-4). Diğer taraftan iş kalitesi kavramı, 2000 yılından itibaren, $A B$ büyümesinin ve istihdam stratejisinin kapsayıcı hedeflerinden biri olmuştur. Stratejide temel amaç sadece daha fazla iş değil, aynı zamanda daha iyi işler yaratmak olmuştur (Kauhanen ve Nätti, 2015: 783). Bu anlamda, 2001 y1lında AB'ye üye ülkelerin bu alandaki performanslarını izlemek ve karşılaştırmak için "Laeken göstergeleri" olarak bilinen ve 10 boyutlu bir gösterge ile ölçülen geniş bir iş kalitesi kavramı kabul edilmiştir. Bu göstergeler sadece içsel iş kalitesi, beceriler ve yaşam boyu öğrenme gibi işin özelliklerine ve iş kalitesine ilişkin göstergeleri değil, aynı zamanda sosyal diyalog ve çalışan katılımı ve genel ekonomik durum, performans ve verimlilik gibi, daha geniş işgücü piyasası ölçümlerini de içermektedir (European Commission, 2008: 153). Daha sonra Eurofound (2002) iş kalitesini ölçmeye yönelik iş kalitesinin değerlendirilmesinde kullanılmak üzere kariyer ve istihdam güvenliği, çalışanların sağlığ 1 ve mutluluğu, beceri geliştirme ve iş-yaşam dengesinden oluşan dört ana boyutu olan analitik bir çerçeve önermiştir. Bu çerçevede, istihdam durumu, gelir, sosyal koruma ve işçi hakları göstergeleri kariyer ve istihdam güvencesini içermekte; sağlık sorunları, riske maruz kalma ve iş organizasyonu ise, sağlık ve mutluluk göstergeleri olarak kullanılmaktadır. Beceri geliştirme göstergeleri ise, nitelikler, eğitim, öğrenen organizasyon ve kariyer gelişimini içermekteyken, iş veya iş dışı zaman ve sosyal altyapılar iş-yaşam dengesini ölçmektedir (Eurofound 2002: 6).

Tablo 1: OECD İş Kalitesi Göstergeleri

\begin{tabular}{|c|c|c|}
\hline Boyutlar & $\begin{array}{c}\text { İş kalitesinin toplam sonuç } \\
\text { ölçüsü }\end{array}$ & Göstergeler \\
\hline Kazanç kalitesi & $\begin{array}{l}\text { Hem kazanç seviyesini hem de } \\
\text { dağılımını (eşitsizlik) dikkate } \\
\text { alan kazanç endeksi }\end{array}$ & - Kazanç seviyesi \\
\hline İşgücü piyasası güvencesizliği & $\begin{array}{l}\text { Işsizlikle ilişkili beklenen } \\
\text { kazanç kaybı }\end{array}$ & $\begin{array}{l}\text { - İşsizlik riski } \\
\text { - İşsizlik sigortası }\end{array}$ \\
\hline Çalışma ortamı kalitesi & $\begin{array}{l}\text { İş zorlanması yaşayan } \\
\text { çalışanların oranı (iş stres } \\
\text { faktörleri ve işyeri kaynakları } \\
\text { arasındaki dengesizlik) }\end{array}$ & $\begin{array}{l}\text { İşle ilgili stres faktörleri } \\
\text { - Fiziksel sağlık risk faktörleri } \\
\text { - Çalışma sürelerinin ineslaktikliği } \\
\text { - Uzun çalışma süreleri } \\
\text { İş görevlerini yerine getirmek için } \\
\text { gereken destek ve kaynaklar } \\
\text { - İş otonomisi ve öğrenme firsatları } \\
\text { - Eğitim ve öğrenme } \\
\text { - Kariyer ilerlemesi firsatı }\end{array}$ \\
\hline
\end{tabular}

Kaynak: (OECD, 2014: 87). 
Son olarak OECD (2014), Stiglitz-Sen-Fitoussi Komisyonu'nun (Stiglitz vd., 2009) çalışan mutluluğunun sekiz boyutunu belirleyen raporuna dayanarak, bir "İş Kalitesi Çerçevesi" geliştirmiştir. Bu çerçeve, Stiglitz-Sen-Fitoussi Raporu'nda da tavsiye edildiği gibi, özellikle bireysel sonuçlara daha fazla önem vermek ve ülke ortalamalarının ötesine geçmek için daha geniş bir çalışan mutluluğu kılavuz ilkelerini ortaya koymaktadır. Dolayısıyla bu yaklaşım, iş kalitesini etkileyen faktörlerden ziyade, çalışanların deneyimlediği düşük ücret ve işle ilgili tehlikeler gibi iş kalitesi sonuçlarına odaklanmaktadır (Cazes vd., 2016: 13). İş kalitesinin ölçülmesine ve değerlendirilmesine yönelik OECD İş Kalitesi Çerçevesi, kapsamlı bir iş kalitesi değerlendirmesi yapmak amacıyla nesnel ve ölçülebilir boyutları dikkate almaktadır (OECD, 2016: 1). Tablo 1'de görüldüğü gibi, OECD İş Kalitesi çerçevesinde insanların istihdam durumlarıyla yakından ilgili olan 9 gösterge, kazanç kalitesi, işgücü piyasası güvencesizliği ve çalışma ortamı kalitesi olmak üzere üç boyut etrafında yapılandırılmıştır (Cazes vd., 2016).

$\mathrm{Bu}$ çalışma kapsamında kısmi süreli istihdamın kalitesini araştırmaya geçmeden önce kısmi süreli istihdam hacmini ile iş kalitesi arasında nasıl bir ilişki olduğunun değerlendirilmesi son derece önemlidir. Bu açıdan bir sonraki bölümde kısmi süreli istihdam hacmini ile iş kalitesi arasındaki ilişkiyi açıklayan literatür incelenecektir.

\section{KISMİ SÜRELİ İSTIHDAM HACMİ İLE İŞ KALITTESİ ARASINDAKİ İLIŞKİ}

İstihdam politikalarının en bilinen amacı, işgücüne katılımı ve istihdam yaratmayı teşvik ederek, istihdam hacmini artırmaktır. $\mathrm{Bu}$ anlamda istihdam ve işsizlik oranları, istihdam hacminin en temel iki göstergesidir. Ancak bu göstergelerin, işgücünün mevcut potansiyelinden yararlanma açısından, işgücü piyasası performansına ilişkin eksiksiz bir bakış sağlayıp sağlamadığı tartışmalıdır. Yine de, potansiyel işgücü arzını harekete geçirmedeki başarı açısından ülkeleri kıyaslarken, istihdam oranları önemli bir göstergedir (OECD, 2017: 25). Diğer taraftan, iş kalitesi veya daha genel manada işgücü piyasası performansı ile istihdam oranları arasında pozitif ilişki kuran hem teorik hem de ampirik argümanlar bulunmaktadır. Bu iki değişken arasındaki pozitif bağlantıya ilişkin ekonomi literatüründe, iki temel argüman ileri sürülmektedir. İlki, beşeri sermaye ile ekonomik büyüme arasında ilişki kuran yaklaşımlardır. Bunların en ünlüsü, beşeri sermaye birikiminin büyüme oranını artırdığını ileri süren Lucas'ın (1988) ünlü içsel büyüme modelidir. Bu modele göre, eğitim ve öğretime yapılan yatırım, artan getiri sağlayarak, olumlu dışsallıklar yaratmakta, yani daha yüksek bir eğitim düzeyi, yalnızca bireysel verimliliği değil, aynı zamanda diğer çalışanların da verimliliğini artırmaktadır. İkincisi ise, çalışan güvenliği ile ekonomik büyüme arasında ilişki kuran yaklaşımlardır. Buradaki güvenlik, istihdam korumasının yanı sıra, güvenli çalışma koşulları, adil ücretler ve sosyal korumaya erişim de dahil olmak üzere, geniş bir perspektifte ele alınmaktadır (Erhel ve Guergoat-Larivière, 2010: 7). Buna göre, genel olarak, çalışanların ekonomik güvenliğini artırmak, çalışan verimliliği ve istihdamı artırarak, ekonomik büyüme üzerinde doğrudan bir etki oluşturabilmektedir (Mathers ve Slater, 2014: 18). Bu açıdan 1970-1998 dönemini kapsayan 21 OECD ülkesinden oluşan yıllık verileri kullanan Arjona vd. (2002), verimliliği ve istihdamı artırmayı amaçlayan aktif programlara yapılan harcamalardaki marjinal bir artışın (\%0,63'ten $\% 0,73$ 'e), uzun vadeli ekonomik büyümeyi yaklaşık \%1 oranında artıracağ1 sonucuna ulaştılar. Dolayısıyla, iş kalitesindeki artış da, çalışanların verimliliğini artırarak, ekonomik büyüme ve istihdam üzerinde olumlu bir etki yaratabilir (Erhel ve Guergoat-Larivière, 2010: 7).

Son yıllarda tam zamanlı işlerin OECD ortalaması düşerken, kısmi süreli istihdam oranları bir artış eğilimi göstermektedir. Ancak bu işgücü istatistikleri, kısmi süreli işlerin dağılımı, yapısı ve koşullarıyla ilgili birtakım bilgiler vermesine rağmen, kısmi süreli işlerin kalitesiyle ilgili çok az bilgi sunmaktadır (McDonald vd., 2009: 143). Bu anlamda, kısmi süreli istihdam artışının sorunlu olup olmadığ 1 , bu işlerin kalitesine bağlıdır. Ancak, kısmi süreli işlerin kalitesine yönelik farklı görüşler de bulunmaktadır. İlk olarak, kısmi süreli istihdamın hem 
işverenlere hem de çalışanlara fayda sağladığını ileri süren bazı görüşler bulunmaktadır (Kalleberg vd., 2000: 256-257). Örneğin Avrupa Çalışma Koşulları Araştırmasına göre, iş kalitesi ve çalışma koşulları emeklilik kararlarını etkilemekte ve yaşlanan toplumlarda önemli bir politika hedefi olan çalışanların istihdamda kalma sürelerini uzatan önemli bir faktör oluşturmaktadır (Eurofound, 2008: 19). İkinci olarak, kısmi süreli çalışma biçiminin doğasında bulunan esnekliğin, sadece işverenlerin operasyonel esneklik sağlamalarına ve işgücü maliyetlerini azaltmalarına olanak sağladığını öne sürenler bulunmaktadır. Bu çerçevede, kısmi süreli işlerin düşük ücret ödediği, sağlık ve sosyal güvenceden yoksun olduğu, belirsiz süreli olduğu ve sendikalar ile iş kanunlarının sağladığı korumaların dışında kaldığı ölçüde, çalışanlar açısından sorun oluşturduğu görüşü ağırlık kazanmaktadır (Kalleberg vd., 2000: 256-257). Bu bağlamda, işlerinin kalitesine ilişkin, geçici ve kısmi süreli çalışanların, daimî ve tam zamanlı çalışanlara kıyasla, genellikle daha düşük iş güvencesine sahip olmaları, sosyal güvenlik yardımlarına kısıtlı erişim ve işyeri eğitim firsatlarından yararlanmada dezavantajlara sahip olmaları gibi, bir takım olumsuz çalışma koşullarının olduğuna dair ampirik bulgular bulunmaktadır (Eurofound, 2002; Kauhanen ve Nätti, 2015: 784). Ancak kısmi süreli istihdamın bu olumsuz özelliklerini azaltmaya yönelik bazı ülkeler, ücretler, diğer çalışma koşulları ve kariyer beklentileri açısından, kısmi süreli işlerin kalitesini tam zamanlı işler ile eşitlemek için eşit davranma mevzuatını ve diğer önlemleri uygulama konusunda, diğer ülkelerden daha fazla yol kat etmiştir. Daha az sayıdaki ülke ise, daha da ileri giderek, tam zamanlı çalışanların çalışma sürelerini kısmi süreliye dönüştürme hakkı veren bazı yasal düzenlemeler yapmıştır (Fagan vd., 2014: 41).

Literatürde, iş ve aile veya diğer iş dışı sorumluluklar arasında denge kurmanın bir yolu olarak kısmi süreli istihdama önemli bir vurgu yapılırken, yine de iş-yaşam dengesi sadece azalan çalışma sürelerine değil, aynı zamanda iyi çalışma programları, istihdam güvenliği ve standart çalışma haklarına erişim gibi, diğer iş özelliklerine de bağlıdır (McDonald vd., 2009: 143). Bu anlamda iş kalitesiyle ilgili "iyi işler/kötü işler", "insana yakışır iş", "güvencesiz iş" ve "taşeron iş" gibi tamamlayıcı temalarla bağlantılı önemli ölçüde bir literatür bulunmaktadır. Bu literatürün çoğu, standart tam zamanlı işlerin tartışılmasına yönelik olmasına rağmen, tartışmayı kısmi süreli işlere kadar genişleten bazı çalışmalar da bulunmaktadır. Örneğin Tilly (1996), kısmi süreli işleri kötü işlerden ayırmak için, vasıflı çalışanları elde tutmaktan firma için öncelikli olmayan "ikincil işlere" kadar ücretler; beceri, eğitim ve sorumluluk; işgücü devri ve kariyer ilerlemesinden oluşan dört grup temel iş özelliğini incelemiştir (Warren ve Lyonette, 2020: 385-386). Diğer taraftan Kalleberg vd. (2000), çağrı üzerine gündelik çalışma, geçici çalışma, taşeron çalışma, bağımsız çalışma, kendi hesabına serbest çalışma ve geleneksel işlerde kısmi süreli çalışma gibi, standart dışı istihdam ile kötü iş özelliklerine maruz kalma arasındaki ilişkiyi araştırmıştır. Bu çalışmada düşük maaşlı ve sağlık sigortası ile emeklilik yardımlarından yoksun işler “kötü işler" olarak tanımlanmış ve ABD'deki işlerin yaklaşı 1/7'sinin bu üç boyut açısından kötü iş olduğu sonucuna ulaşılmıştır. Ayrıca, Avustralya'da kısmi süreli iş kalitesi üzerine bir çalışma yürüten McDonald vd. (2009) güçlü toplu pazarlık düzenlemelerinin yanı sıra, önemli yasal ve endüstriyel yükümlülüklere rağmen, kısmi süreli iş kalitesine ilişkin sorumlulukların azalması ve yüksek statülü rollere ve projelere daha az erişim, kısıtlı terfi imkanları, artan iş yoğunluğu ve zayıf işyeri desteği açısından bazı sorunların olduğu sonucuna ulaşmıştır. Bununla birlikte, iş kalitesini tam zamanlı çalışma ve gönülsüz kısmi süreli çalışma temelinde ele alan çalışmalar da bulunmaktadır. Örneğin Kauhanen ve Nätti (2015) 2008 Finlandiya Çalışma Yaşam Kalitesi anketini kullanarak, iş sözleşmesi türlerinin algılanan iş kalitesi üzerindeki etkisini incelemişlerdir. Bu çalışmada, gönülsüz kısmi süreli çalışanların iş kalitelerine ilişkin deneyimlerinin, tam zamanlı çalışanlara kıyasla, eğitim olanakları, işveren tarafindan finanse edilen eğitime katılım, kariyer olanakları, işin öğrenme ve gelişme olanakları, iş güvencesi ve iş özerkliği gibi, temel iş kalitesi göstergeleri açısından daha zayıf olduğu sonucuna ulaşılmıştır. 
Çalışmanın buraya kadar ki kısımlarında kısmi süreli istihdam, uluslararası örgütlerin iş kalitesini ölçmeye yönelik yürüttüğü çalışmalar ve kısmi süreli istihdam hacmini ile iş kalitesi arasındaki ilişkiyi açıklayan literatür incelenmiştir. Çalışmanın geri kalan kısmında kısmi süreli istihdam ile iş kalitesi göstergeleri arasındaki ilişki ampirik olarak analiz edilecektir.

\section{ARAŞTIRMA YÖNTEMI}

\subsection{Veri}

İş kalitesi, çalışanların refahına katkıda bulunan ve doğası gereği çok boyutlu bir yapıyı temsil eden istihdamın farklı yönlerini yansıtmaktadır. Şüphesiz ücretler, işlerin en önemli bileşenidir, ancak bir işi kaliteli veya kalitesiz olarak sınıflandırmak için ücreti tek gösterge olarak kullanmak hatalıdır ve bu nedenle bir dizi ek gösterge daha geliştirilmiştir (Warren ve Lyonette, 2020: 385). Yukarıda, OECD veri tabanında OECD İş Kalitesi Çerçevesinin üç temel boyutta yapılandırıldığından bahsetmiştik. Bu veri tabanı, çoğu OECD ülkesi için kazanç kalitesi ve işgücü piyasası güvencesizliğine ilişkin 2006-2015 dönemine ait veriler sağlarken, çalışma ortamı kalitesine ilişkin sadece bazı ülkelerinin 2010 ve 2015 yıllarına ait verileri mevcuttur (OECD, 2021). Bu yüzden, çalışma kapsamında, 2015 verisi mevcut olan ülkeler için 2015 yılı verileri, mevcut olmayan ülkeler için ise, en güncel yıla ait veriler kullanılmıştır. Daha sonra Mahalanobis testi ile tespit edilen uç değerlerin veri setinden çıkarılması sonucu, kalan 34 ülkenin verisi analize dahil edilmiştir. Bu anlamda, çalışmada kullanılan veriler ve verilerin hangi yıla ait olduğu EK'te detaylı bir şekilde gösterilmiştir. Tablo 2'de ise, bu çalışmada kullanılan değişkenlerin deskriptif analiz sonuçları gösterilmektedir.

Tablo 2: Deskriptif İstatistikler

\begin{tabular}{lcccc}
\hline & N & Ortalama & Std. Sapma & $\begin{array}{c}\text { Kolmogorov- } \\
\text { Smirnov }\end{array}$ \\
\hline Kısmi süreli istihdam \% & 34 & 9,15 & 4,94 & $0,087 *$ \\
\hline Kazanç kalitesi \$ & 34 & 17,55 & 8,41 & 0,179 \\
\hline İsücü piyasası güvencesizliği \% & 34 & 5,39 & 4,67 & 0,236 \\
\hline İs zorlanma oranı & 34 & 27,53 & 6,76 & $0,107 *$ \\
\hline Fiziksel sağlık risk faktörleri \% & 32 & 30,19 & 5,94 & $0,099 *$ \\
\hline Ĕgitim ve öğrenme \% & 32 & 54,47 & 13,00 & $0,103 *$ \\
\hline Kariyer ilerleme fırsatı \% & 32 & 18,35 & 9,98 & 0,202 \\
\hline
\end{tabular}

Kaynak: (OECD Stat, 2021).

* İstatistiksel olarak anlamlı.

Tablo 2'de gösterilen değişkenlerin tamamı metrik (sürekli) verilerden oluşmaktadır. Bu açıdan, değişkenlerin normal dağılım gösterip göstermediğine ilişkin, çan eğrisi ve KolmogorovSmirnov testleri yapılmış ve test sonuçlarında örneklemin, bir miktar tolerans dahilinde, normal dağılım gösteren bir gruptan alındığı görülmüştür. Ayrıca standart sapma değerlerinin, belirli bir toleranslar dahilinde, verilerin ortalama (mean) etrafında yoğunlaştığ gözlenmektedir. Böylece değişkenlerin parametrik veri analiz yöntemlerine uyumlu olduğu anlaşılmaktadır. 


\subsubsection{Bağımlı değişken}

Kısmi süreli istihdamı nitelemek için her ülkenin kesme noktası değişkenlik göstermekle birlikte, OECD istatistiklerinde ülkeler arasında karşılaştırma yapabilmek için kesme noktası olarak, haftalık 30 saatlik çalışma süresi kullanılmaktadır. Ayrıca OECD veri tabanında, ülkelere ait kısmi süreli ve tam zamanlı istihdam oranları, toplam istihdam içindeki yüzdelik dağılım biçiminde gösterilmektedir (OECD, 2021). Bu yüzden, kısmi süreli istihdamın toplam istihdam içindeki oranını belirlemek için her bir ülkenin kısmi süreli istihdam dağılım oranının toplam istihdam oranı içindeki payı hesaplanmış ve bu oranlar kullanılmıştır.

\subsubsection{Bağımsız değişkenler}

Kazanç kalitesi, çalışanların işlerinde elde ettikleri kazançların hem ortalama seviyesini, hem de kazançların işgücüne dağıtım şeklini hesaba katarak, çalışan refahına ne ölçüde katkıda bulunduğunu ifade etmektedir (OECD, 2017: 27). Kazanç seviyesi, çalışanların maddi yaşam standartlarına katkılarını değerlendirmek için önemli bir kıyas sağlarken, kazançların işgücüne dağıtım şekli de çalışan mutluluğu için önemlidir. Bu nedenle OECD hem kazanç düzeyini, hem de kazancın işgücüne dağılımını açılayan bir endeksle kazanç kalitesini ölçmektedir (OECD, 2016: 1). Ancak kazanç kalitesi, bireysel kazançların ölçülmesi ve kazanç seviyesi ve dağılımına ilişkin bilgilerin birleştirilmesi için bir seçim yapılmasını gerektirmektedir. Bireysel düzeyde kazançlar, brüt veya net olarak saatlik, aylık ve hatta yıllık olarak ölçülebilir. OECD İş Kalitesi Çerçevesinde, brüt saatlik ücretlerden yararlanmanın yanı sıra, çalışma sürelerindeki farklılıkları iş kalitesinden arındırmak için saatlik ücretler kullanılmıştır. Diğer taraftan, kazanç düzeyi ve dağılımı ile ilgili bilgileri bir araya getirmek için ortalama kazanç, kazanç eşitsizliği derecesi ve düşük ücret oranı gibi göstergelerin bir kombinasyonu kullanılmaktadır (Cazes vd., 2016: 22).

İşgücü piyasası güvencesizliği , ekonomik güvencenin iş kaybı olasıllı̆̆ ve iş kaybının çalışanlara ekonomik maliyeti ile ilişkili yönlerini ele almaktadır (OECD, 2016: 1). Bu gösterge hem işsizlik riskini (işsiz kalma riski ve beklenen işsizlik süresi), hem de kamu işsizlik sigortasının derecesini (yardımların kapsamı ve cömertliği) ölçmektedir (OECD, 2017: 27). Bu anlamda etkili işsizlik sigortası, yardımların kapsamı ve işsizlerin faydalandığ 1 kamu transferlerinin kazanç kayıplarını ikame oranları olarak tanımlanmaktadır. Bu oran, işsizlik ödeneği almanın ve ödeneklerin cömertliğinin birleşik etkisini yansıtmakta ve OECD ülkeleri için kullanılan etkin (net) ikame oranı kavramı ile tutarlıdır (Cazes vd., 2016: 23).

Çalışma ortamı kalitesi, yapılan işin doğası ve içeriği, çalışma süresi düzenlemeleri ve iş ilişkileri ile ilgili faktörleri içermektedir (OECD, 2016: 1). Bu nedenle, çalışma ortamının kalitesi, iş kalitesinin ekonomik olmayan yönlerini yansıtmakta ve işle ilgili stres faktörleri ile iş görevlerini yerine getirmek için gereken destek ve kaynakların bir birleşimi ile karakterize edilen iş zorlanmasının görülme sıklığı ile ölçülmektedir (OECD, 2017: 27). Burada iş zorlanması, çalışanların iş görevleri için gereken destek ve kaynak miktarından daha fazla işle ilgili stres faktörleri ile karşılaşmaları olarak tanımlanmaktadır. Bu açıdan, üç tür işle ilgili stres faktörü tanımlanmaktadır. İlki, gürültüye, titreşime, yüksek ve düşük sıcaklığa maruz kalmak gibi tehlikeli işler ile nakliye ve ağır yüklerin taşınması, acı verici ve yorucu işler gibi ağır işlerde çalışmaktan kaynaklanan fiziksel sağlık risk faktörleridir (OECD, 2017: 27; Cazes vd., 2016: 24-25). Bu anlamda fiziksel sağlık risk faktörleri, bir işin çalışanların sağlığını potansiyel olarak bozabilecek risk faktörlerini içerme derecesini ifade etmektedir (OECD, 2021). İkincisi, çalışma süreleri ineslaktikliği ve üçüncüsü de uzun çalışma süreleri (haftada 60 saatten fazla) oranıdır. Aynı şekilde, iş görevlerini yerine getirmek için gereken üç tür destek ve kaynak dikkate alınmaktadır. İlki iş otonomisi ve öğrenme firsatları; ikincisi, yaptığı işle ilgili eğitim aldığını bildiren işçi sayısını ifade eden e çalışanların yüzdesini ifade eden kariyer ilerleme firsatı oranıdır (OECD, 2021). 


\subsection{Korelasyon Analizi}

Korelasyon analizi, iki değişken arasındaki doğrusal ilişkiyi veya bir değişkenin iki ya da daha fazla değiş̧enle olan ilişkisini test etmek, varsa bu ilişkinin derecesini ölçmek için kullanılan istatistiksel bir yöntemdir. Korelasyon analizi, bağımsız değişken (X) değiştiğinde, bağımlı değişkeninin (Y) ne yönde değişeceğini görmeyi amaçlamaktadır (Sungur, 2014: 115).

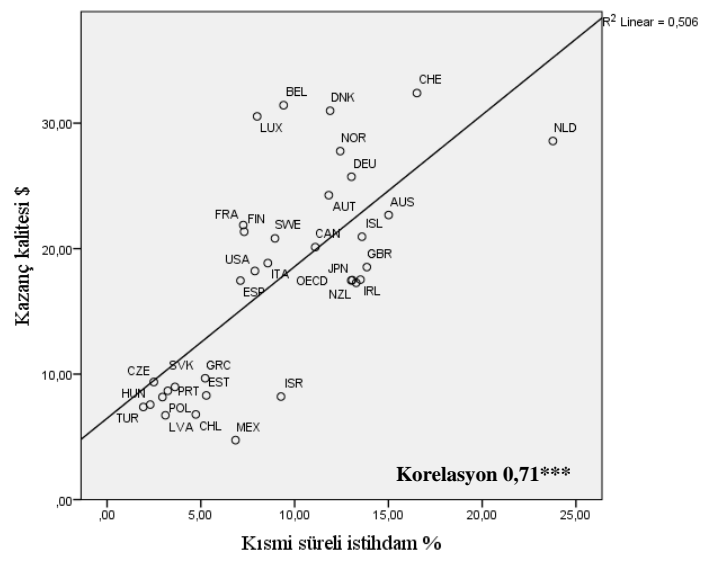

Grafik 1: Kısmi süreli istihdam ile kazanç kalitesi arasındaki ilişki

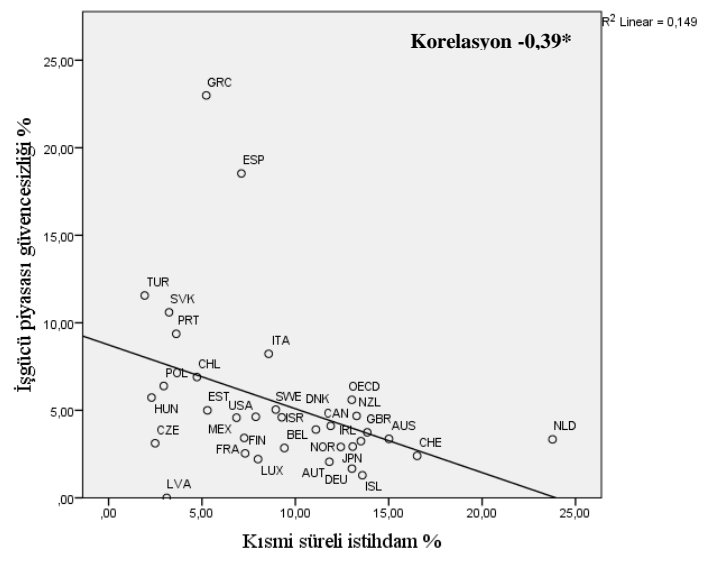

Grafik 2: Kısmi süreli istihdam ile işgücü piyasası güvencesizliği arasındaki ilişki

Kaynak: (OECD Stat, 2021).

İstatistiksel anlamlılık düzeyi $* p<0,05 ; * * p<0,01 ; * * * p<0,001$.

Grafik 1'de kısmi süreli istihdam oranının yüksek olduğu, özellikle Hollanda, İsviçre, Danimarka, Norveç, Almanya, Belçika ve Lüksemburg'da, kazanç kalitesinin de anlamlı bir şekilde yüksek olduğu görülmektedir. Buna göre, kısmi süreli istihdam ile kazanç kalitesi arasında pozitif yönlü yüksek düzeyli anlamlı $(\mathrm{r}=0,71 ; p<0,001)$ bir korelasyon gözlenmektedir. ILO'nun 175 sayılı Sözleşmesi'nde, eşit davranmanın kısmi süreli çalışanların saatlik ücretlerinin tam zamanlı çalışanlarla aynı olmasını içerdiği belirtilmesine rağmen, kısmi süreli çalışanlar ile tam zamanlı çalışanlar arasında saat başı kazanılan ücretler açısından önemli farklılıklar bulunduğu bilinmektedir. Bu anlamda kısmi süreli çalışanlar, orantısız bir şekilde ücret dağılımının en dibinde toplanmaktadır (Tilly, 1996: 53). OECD (2010) araştırmasına göre, eğitim, terfi ve sendika üyeliği gibi gelecek kazanç potansiyeline katkıda bulunan faktörler düşünüldüğünde, kısmi süreli çalışanlar daha kötü durumdadır. Bu anlamda Avrupa, Kuzey Amerika, Güney Amerika, Avustralya, Yeni Zelanda, Japonya ve Kore gibi ülkelerde kısmi süreli çalışanlar, daha düşük ortalama saatlik kazançlara sahipken, Norveç ve Hollanda'nın dahil olduğu birkaç ülkede kısmi süreli ve tam zamanlı çalışanlar arasında ortalama kazanç farkı neredeyse hiç yoktur (Fagan vd., 2014: 32).

İş kaybı tehdidi ve güvencesizliği bağlamında iş kalitesinin bir diğer boyutu, kısmi süreli işlerin güvenceli olup olmadığına ilişkindir (Warren ve Lyonette, 2020: 386). Bu anlamda Grafik 2'ye göre, kısmi süreli istihdam ile işgücü piyasası güvencesizliği arasında negatif yönlü orta düzey anlamlı $(\mathrm{r}=-0,39 ; p<0,05)$ bir korelasyon gözlenmektedir. Ayrıca, OECD ülkeleri arasında işgücü piyasası güvencesizliğinin en yüksek olduğu ilk iki ülke açık ara Yunanistan ve İspanya'dır. Bu sonuç, bazı ülkelerde kısmi süreli çalışanların sosyal koruma haklarına ve yardımlarına sınırlı bir erişim sağladığını bildiren, Avrupa Çalışma Koşulları Araştırması'nı da teyit etmektedir (Eurofound, 2007: 17). Genel olarak bakıldığında, çalışanların belirsiz süreli iş sözleşmesine sahip olup olmadıkları ya da öznel olarak, işlerinde kendilerini güvenceli hissedip hissetmedikleri objektif olarak ölçüldügünde, genellikle geçici veya kısa süreli işlerde istihdam 
edildikleri için kısmi süreli çalışanların, tam zamanlı çalışanlara göre, daha düşük iş güvencesine sahip olduğu kabul edilmektedir (Fagan vd., 2014: 30). Düşük iş güvencesinin yanı sıra, kısmi süreli çalışanların işlerini kaybetmeleri durumunda, işsizlik sigortasına hak kazanma olasılıkları da oldukça düşüktür (OECD, 2010: 224). Çünkü işsizlik sigortasından yararlanabilmek için belirli bir süre çalışarak işsizlik sigortası primi ödeme koşulu bulunduğu için hem kayıtlı kısmi süreli çalışanların bu koşulları sağlaması oldukça zordur, hem de kısmi süreli istihdamda kayıt dış1lık görece daha yüksektir.

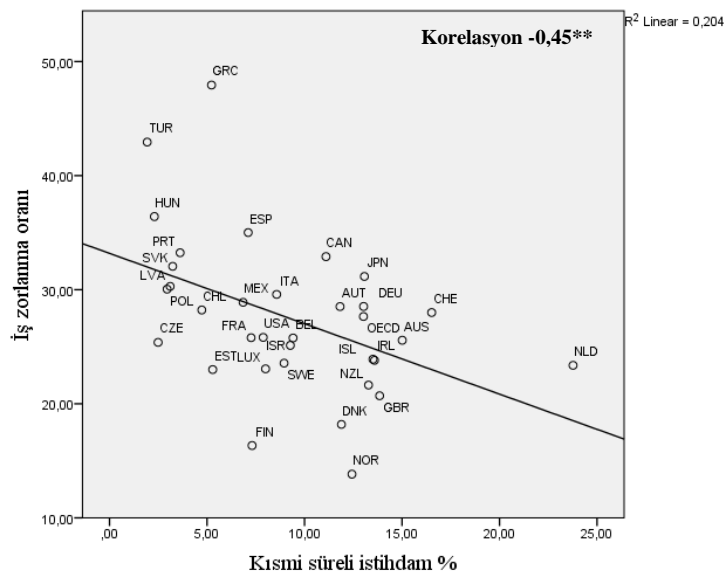

Grafik 3: Kısmi süreli istihdam ile iş zorlanma oranı arasındaki ilişki

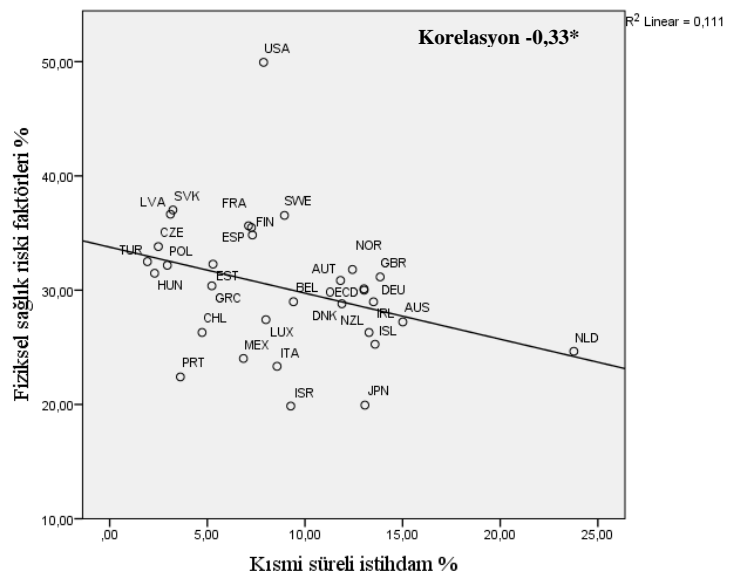

Grafik 4: Kısmi süreli istihdam ile fiziksel sağlık risk faktörleri arasındaki ilişki

Kaynak: (OECD Stat, 2021).

İstatistiksel anlamlılık düzeyi $* p<0,05 ; * * p<0,01 ; * * * p<0,001$.

Grafik 3'te kısmi süreli istihdam ile iş zorlanma oranı arasında negatif yönlü orta düzey anlamlı $(\mathrm{r}=-0,45 ; p<0,01)$ bir korelasyon görülmektedir. Diğer ülkelerden negatif ayrışan Yunanistan, Türkiye ve Macaristan'da iş zorlanma oranları oldukça yüksek olmasına karşın, pozitif ayrışan Norveç, Finlandiya ve Danimarka'da iş zorlanma oranlarının çok düşük olması, iki değişken arasındaki korelasyonu zayıflatmaktadır. Bu sonuç negatif ayrışan ülkelerde işle ilgili stres faktörlerinin görece daha yüksek, pozitif ayrışan ülkelerde nispeten daha düşük olduğunu anlamına gelmektedir.

Çalışma ortamı kalitesinin alt göstergelerinden biri olan fiziksel sağlık risk faktörleri, çalışanların işlerini yaparken tehlikelere ve sağlı risklerine maruz kalma oranlarını göstermektedir. Bu açıdan Grafik 4'te kısmi süreli istihdam ile fiziksel sağlık risk faktörleri arasında negatif yönlü orta düzey anlamlı $(\mathrm{r}=-0,33 ; p<0,05)$ bir korelasyon görülmektedir. Ayrıca fiziksel sağlık risk faktörleri açısından özellikle ABD negatif ayrışırken, İsrail ve Japonya'nın pozitif ayrıştığı izlenmektedir. 


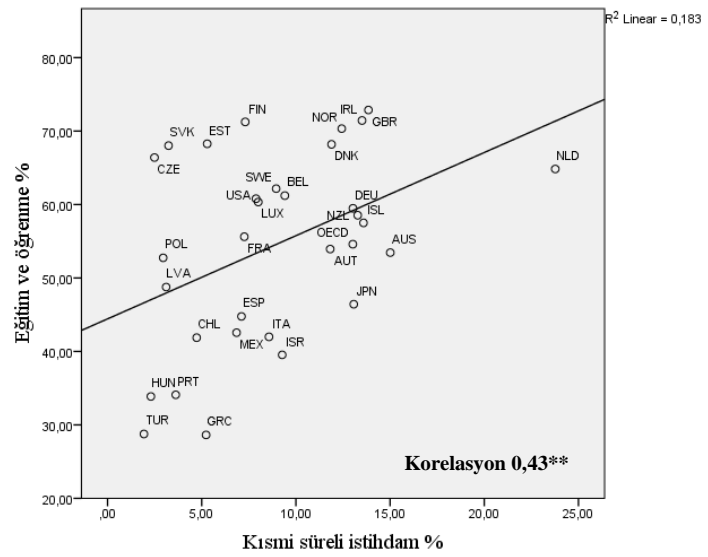

Grafik 5: Kısmi süreli istihdam ile eğitim ve öğrenme arasındaki ilişki

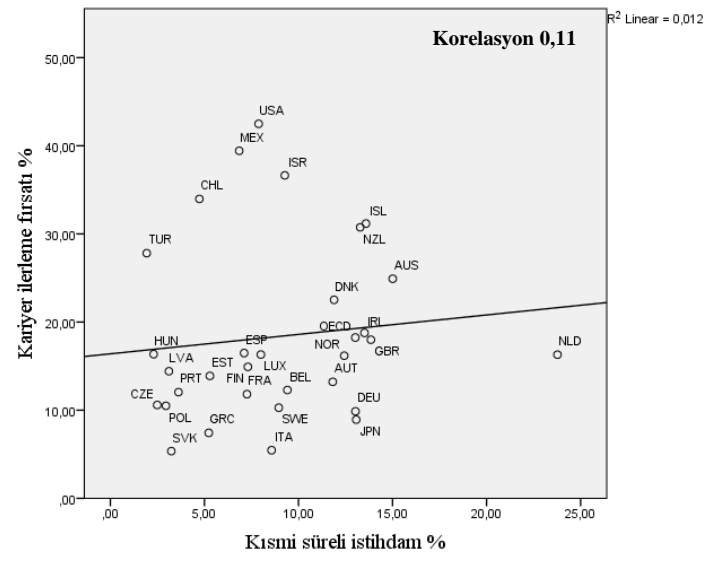

Grafik 6: Kısmi süreli istihdam ile kariyer ilerleme fırsatı arasındaki ilişki

Kaynak: (OECD Stat, 2021).

İstatistiksel anlamlılık düzeyi $* p<0,05 ; * * p<0,01 ; * * * p<0,001$.

Grafik 5 ve 6'da görüldüğü gibi, kısmi süreli istihdam ile eğitim ve öğrenme arasında pozitif yönlü orta düzey anlamlı $(\mathrm{r}=0,43 ; p<0,01)$ bir korelasyon bulunuyorken, kısmi süreli istihdam ile kariyer ilerleme firsatı arasında anlamlı bir korelasyon tespit edilememiştir. Ancak eğitim ve öğrenme oranları İskandinav ülkelerinin yanı sıra, Birleşik Krallık ve İrlanda'da daha yüksekken, kariyer ilerleme firsatlarının ABD, Meksika, İsrail ve İsviçre'de daha yüksek olduğu gözlenmektedir. $\mathrm{Bu}$ sonuçlara rağmen, kısmi süreli çalışanlar işyerinin sunduğu eğitim imkanlarından daha az faydalanabilmekte ve bu da onların kariyer gelişimi firsatlarını azaltan bir etki oluşturmaktadır (Fagan vd., 2014: 31).

\subsection{Araştırma Modeli ve Hipotezleri}

$\mathrm{Bu}$ çalışmaya ilişkin araştırma modelinin bağımsız değişkeni kısmi süreli istihdam hacmi, bağımlı değişkenleri ise, kısmi süreli iş kalitesini etkilediği düşülen "kazanç kalitesi, işgücü piyasası güvencesizliği, iş zorlanma oranı, fiziksel sağllk risk faktörleri, eğitim ve ögrenme ile kariyer ilerleme firsatı"dır. Oluşturulan model çerçevesinde, araştırma hipotezleri ise, şu şekilde geliştirilmiştir:

" $H_{0}=$ iş kalitesi göstergelerinden hiç biri kusmi süreli istihdam hacmini anlamlı bir şekilde açılkayamamaktadır."

" $H_{1}=i$ ş kalitesi göstergelerinden en az biri klsmi süreli istihdam hacmini anlamlı bir şekilde açılamaktadır."

\subsection{Analiz Tekniği}

Araştırmanın hipotez testi için parametrik verileri tahmin etmeye yarayan bir modelleme tekniği olan doğrusal regresyon analizi kullanılacaktır. Basit doğrusal regresyonda, bağımsız bir değişken $(x)$ ile bağımlı değişkeni $(y)$ tahmin etmek için iki değişkenli bir model oluşturulmaktadır. Eğer model bağımlı değişkeni $(y)$ tahmin etmek için birden fazla bağımsız değişken içeriyorsa, bu durumda çoklu doğrusal regresyon teknikleri kullanılabilir (Brown, 2009: 1; Tranmer vd., 2020: 6). Çoklu doğrusal regresyonda, aslında model birden fazla bağımsız değişkeni $\left(\mathrm{x}_{1}, \mathrm{x}_{2}, \ldots ., \mathrm{x}_{\mathrm{p}}\right)$ içerecek şekilde genişletilmektedir. Bu açıdan çoklu doğrusal 
regresyon denklemi, basit lineer regresyonun aynısıdır, ancak daha fazla terime sahiptir (Tranmer vd., 2020: 11). Bu çerçevede çoklu doğrusal regresyon denklemi şu şekilde formüle edilmektedir:

$$
y_{i}=\beta_{0}+\beta_{1} x_{1 i}+\beta_{2} x_{2 i}+\cdots+\beta_{p} x_{p i}+e_{i}
$$

\subsection{Hipotez Testi}

Araştırma kapsamında belirlenmiş olan hipotezleri test etmek için OECD ülkelerine ait iş kalitesi göstergelerini kullanarak, kısmi süreli istihdam hacmini açıklayan çoklu doğrusal regresyon analizi sonuçları Tablo 3'te gösterilmiştir.

Yapılan analiz sonucunda, kurulan çoklu doğrusal regresyon modelinin anlamlı olduğu $F(6,25)=11,846 ; p<0,001)$ ve bağımlı değişkendeki varyansın \%68'inin $\left(\mathrm{R}^{2}{ }_{\text {adjusted }}=0,68\right)$ bağımsız değişkenler tarafından açıklandığı sonucuna ulaşılmıştır. Tablo 3'deki tolerans değerleri ve VIF değerleri de modelde yer alan bağımsız değişkenler arasında çoklu doğrusal bağlantı sorununun olmadığına işaret etmektedir. Ayrıca Durbin-Watson $(1,633)$ test sonucundan, modelin hata terimleri arasında otokorelasyon sorununun olmadığı anlaşılmaktadır. Böylece çoklu doğrusal regresyon analizinin bütün varsayımları karşıladığını söyleyebiliriz.

Tablo 3: Çoklu Doğrusal Regresyon Modeli

\begin{tabular}{|c|c|c|c|c|c|c|c|c|}
\hline \multirow{2}{*}{$\begin{array}{l}\text { Bağımlı değişken: } \\
\text { Kısmi süreli istihdam }\end{array}$} & \multicolumn{2}{|c|}{$\begin{array}{l}\text { Standardize } \\
\text { edilmemiş } \\
\text { Katsayılar }\end{array}$} & \multirow{2}{*}{$\begin{array}{c}\begin{array}{c}\text { Standardize } \\
\text { edilmiş } \\
\text { Katsayllar }\end{array} \\
\text { Beta }\end{array}$} & \multirow[b]{2}{*}{$\mathbf{t}$} & \multirow[b]{2}{*}{ Sig. } & \multicolumn{2}{|c|}{$\begin{array}{l}\text { Doğrusallık } \\
\text { İstatistikleri }\end{array}$} & \multirow[b]{2}{*}{$\begin{array}{l}\text { Durbin- } \\
\text { Watson }\end{array}$} \\
\hline & $\beta$ & $\begin{array}{c}\text { Std. } \\
\text { Hata }\end{array}$ & & & & Tolerans & VIF & \\
\hline (Sabit) & $-11,672$ & 8,815 & & $-1,324$ & 0,197 & & & 1,633 \\
\hline Kazanç kalitesi & 0,371 & 0,074 & 0,631 & 5,016 & 0,000 & 0,657 & 1,522 & \\
\hline İşgücü piyasası güvencesizliği & $-0,016$ & 0,153 & $-0,015$ & $-0,103$ & 0,919 & 0,498 & 2,008 & \\
\hline İş zorlanma oranı & 0,360 & 0,182 & 0,492 & 1,982 & 0,059 & 0,169 & 5,922 & \\
\hline Fiziksel sağlık risk faktörleri & $-0,433$ & 0,106 & $-0,520$ & $-4,107$ & 0,000 & 0,648 & 1,543 & \\
\hline Eğitim ve öğrenme & 0,262 & 0,093 & 0,688 & 2,810 & 0,009 & 0,174 & 5,758 & \\
\hline Kariyer ilerleme firsatı & 0,181 & 0,061 & 0,364 & 2,964 & 0,007 & 0,689 & 1,452 & \\
\hline
\end{tabular}

Kaynak: (OECD Stat, 2021).

$\mathrm{R}^{2}$ adjusted $\left.=0,677 ; F(6,25)=11,846 ; \mathrm{p}<0,001\right)$.

Analiz sonuçlarına göre, kazanç kalitesi $(\beta=0,63 ; t(25)=5,01 ; p<0,001)$ kısmi süreli istihdam hacmini pozitif yönlü ve anlamlı olarak açıkladığı gözlenmektedir. Diğer taraftan, modelde fiziksel sağlik risk faktörleri oranı $(\beta=-0,52 ; t(25)=-4,10 ; p<0,001)$ kısmi süreli istihdam hacmini negatif yönlü ve anlamlı olarak açıklamaktadır. Ayrıca eğitim ve öğrenme oranı $(\beta=0,69 ; t(25)=2,81 ; p<0,01)$ ve kariyer ilerleme firsatı oranının $(\beta=0,36 ; t(25)=2,96$; $p<0,01)$ kısmi süreli istihdam hacmini pozitif yönlü ve anlamlı olarak açıladığı görülmektedir. Ancak modelde işgücü piyasası güvencesizliği ve iş zorlanma oranının kısmi süreli istihdam hacmini anlamlı bir şekilde açıklayamadığı gözlenmektedir. Buna rağmen, elde edilen bulgular " $H_{l}$ " hipotezinin kabul edildiği anlamına gelmektedir. 


\section{SONUÇ}

$\mathrm{Bu}$ çalışmada, kısmi süreli istihdam hacmi ile OECD iş kalitesi göstergeleri arasındaki ilişki, korelasyon ve çoklu doğrusal regresyon analizi teknikleriyle açıklanmaya çalışılmıştır. Elde edilen bulgulara göre, genel olarak, daha yüksek kısmi süreli istihdam oranları, daha iyi iş kalitesiyle ilişkili gözükmektedir. Bu da kısmi süreli istihdam hacmi ile iş kalitesi göstergeleri arasında bir değiş tokuş olmadığını göstermektedir. Çünkü bu ilişki, iş kalitesinin nispeten daha iyi olduğu gelişmiş OECD ülkelerinde kısmi süreli istihdam oranlarının daha yüksek, nispeten daha kötü olduğu gelişmekte olan OECD ülkelerinde ise, daha düşük olmasının bir sonucudur. Böyle bir ilişkiye rağmen, benzer kısmi süreli istihdam oranlarına sahip ülkeler arasında da iş kalitesi seviyeleri açısından önemli farklılıklar bulunmaktadır. Örneğin, Meksika ve Lüksemburg benzer kısmi süreli istihdam oranlarına sahip olmalarına rağmen, kazanç kalitesinin Lüksemburg'da çok daha yüksek olduğu gözlenmektedir.

Çalışma kapsamında yapılan korelasyon analizi sonucunda, kısmi süreli istihdam hacmi ile kazanç kalitesi arasında pozitif yönlü yüksek düzeyli, eğitim ve öğrenme arasında ise, pozitif yönlü orta düzeyli anlamlı bir korelasyon gözleniyorken, kısmi süreli istihdam hacmi ile işgücü piyasası güvencesizliği, iş zorlanma oranı ve fiziksel sağlık risk faktörleri arasında negatif yönlü orta düzeyli anlamlı bir korelasyon bulunmaktadır. Ancak, kısmi süreli istihdam hacmi ile kariyer ilerleme firsatı arasında anlamlı bir korelasyon görülmemiştir. Aslında iş kalitesi sonuçları, çalışanlar ve politika yapıcılar için oldukça önemli olmasına rağmen, iş kalitesini etkileyen faktörler ile iş kalitesi arasında her zaman yüksek bir korelasyon bulunmayabilir (Cazes vd., 2016: 13). Bu yüzden, iş kalitesinin artırılmasında politikaların ve kurumların rolüne odaklanmak, çok daha önemli olabilir.

Çoklu doğrusal regresyon analizinde kazanç kalitesindeki 1 birimlik artışın, kısmi süreli istihdam hacmini 0,37 birim artırabileceği sonucuna ulaşılmıştır. Bu sonuç, kısmi süreli işlerin ücret düzeyindeki artışların, kısmi süreli işlerin çalışanlar açısından kabul edilebilirliğini artırdığını göstermektedir. Ayrıca bu bulgunun daha önceki araştırma sonuçları ile de uyumlu olduğu söylenebilir. Örneğin, Avrupa Çalışma Koşulları Araştırması sonuçlarına göre, en düşük gelir grupları arasında sayılan kısmi süreli çalışanların sabit bir maaş veya ücret alma ve ikramiye ya da prim gibi ek ödemelere hak kazanma olasılıkları daha düşüktür (Eurofound, 2007: 17). Diğer taraftan Britanya'daki kısmi süreli işlerin kalitesini inceleyen Warren ve Lyonette (2015), kısmi süreli işlerin çalışanlara düşük ücret ve sınırlı kariyer ilerleme firsatları sunduğu sonucuna ulaştılar. Ayrıca Kanada, Almanya, İtalya, İsveç, Birleşik Krallık ve ABD'deki kısmi süreli ve tam zamanlı işlerdeki ücret farklılıklarını inceleyen Bardasi ve Gornick (2008), kısmi süreli ve tam zamanlı çalışma biçimleri arasındaki ücret farklılıklarının hem kadınlar, hem de cinsiyetler arasındaki işgücü piyasası eşitsizlikleriyle ilişkili olduğu sonucuna ulaştılar. $\mathrm{Bu}$ iki çalışma biçimi arasındaki saatlik ücret farkı, endüstri ve mesleki pozisyon gibi iş özelliklerinin yanı sıra, eğitim ve iş deneyimi gibi bireysel özelliklerdeki farklılıklar test edildikten sonra bile, devam etmektedir (Bardasi ve Gornick, 2008: 37).

Regresyon analizi fiziksel sağlık risk faktörlerindeki 1 birimlik artışın kısmi süreli istihdam hacmini 0,43 birim düşürebileceğini göstermektedir. Bu sonuca göre, kısmi süreli işlerin kötü ergonomik koşullarının düzeltilmesinin yanı sıra, tehlike ve sağlık risklerini azaltıcı iş güvenliği önlemlerinin ve denetimlerinin artırılması iş kalitesini de artırabilir. Ancak Avrupa Çalışma Koşulları Araştırması'na göre, kısmi süreli çalışanlar yüksek ses, titreşim, tehlikeli maddeleri kullanma/soluma, yüksek/düşük sıcaklıklar, radyasyon gibi bir dizi tehlikeye ve tekrarlayan el/kol hareketleri, ağrılı/yorucu pozisyonlar, ağır yük taşıma gibi kötü ergonomik koşullara daha az maruz kalmaktadırlar (Eurofound, 2007: 15). Diğer taraftan, kısmi süreli işlerin genel olarak, stres veya sağlık ve güvenlik açısından risk olasılığının daha düşük olduğunu belirten OECD (2010) araştırması da bu sonucu teyit etmektedir. Bu anlamda, kısmi 
süreli çalışanların kötü çalışma koşulları bağlamında, tam zamanlı çalışanlara göre, daha iyi durumda olduğu söylenebilir (OECD, 2010: 227).

Regresyon sonuçları eğitim ve öğrenme ve kariyer ilerleme firsatlarındaki 1 birimlik artışın, kısmi süreli istihdam hacmini sırasıyla 0,26 ve 0,18 birim artırabileceğini göstermektedir. Buna göre, işyerinde eğitim ve öğrenme firsatlarından yararlanan çalışan sayısının yanı sıra, kariyer ilerleme firsatlarının artırılması da kısmi süreli istihdamı olumlu yönde etkileyebilir. Geçmiş çalışmalara bakıldığında, örneğin Warren ve Lyonette (2015) kısmi süreli çalışanların, daha az beceri ve düşük eğitim ve öğretim seviyeleri gerektiren kalitesiz işlerde yoğunlaştı̆̆ 1 sonucuna ulaştılar. Tilly (1996) ise, ikincil kısmi süreli işlerin, elde tutulması gereken birincil işlerden daha düşük beceri, eğitim ve sorumluluk seviyeleri içerdiğini ileri sürmüştür. Bu açıdan işverenler, ikincil kısmi süreli işlerde çalışanları kolayca ikame edilebilir kabul etmekte ve onların mesleki gelişimine daha az yatıım yapmaktadır (Tilly, 1996: 60). Avrupa Çalışma Koşulları Araştırması sonuçları da, kısmi süreli çalışanların kısa süreli iş ilişkileri, daha düşük akademik nitelikleri veya daha az karmaşı görevler üstlenmeleri gibi özellikleri nedeniyle işverenlerin onlara daha az eğitim yatırımı yaptıkları sonucunu teyit etmektedir. Bu açıdan, kısmi süreli çalışanlar, tam zamanlı çalışanlara göre, daha kötü iş içeriği, daha düşük kariyer firsatları ve eğitim olanaklarından yeterince yararlanamama gibi sorunlar yaşamaktadır (Eurofound, 2007: 13). Diğer taraftan, daha az eğitim yatırımı kısmi süreli çalışanların sadece mevcut iş kalitesini düşürmekle kalmaz, aynı zamanda gelecekte daha iyi işlere geçme olasıllı̆ını da sınırlandırmaktadır. Yani, kısmi süreli çalışanların düşük sorumluluk gerektiren işlerde yoğunlaşmaları ve eğitim firsatlarının düşük olması gibi bazı engeller, onların kariyer gelişimini olumsuz yönde etkilemektedir (Warren ve Lyonette, 2020: 386). Ayrıca kısmi süreli işlerdeki düşük kariyer firsatları ile düşük ücret kombinasyonu, kısmi süreli çalışanların istihdama dayalı emeklilik sistemlerindeki birikimlerini de olumsuz yönde etkilemektedir (Fagan vd., 2014: 34).

Son söz olarak, bu çalışmanın ulaştı̆̆ı bulgular, kullanılan veri ve örneklem büyüklüğüne bağlı olarak, buzdağının sadece görünen kısmını yansıttığı kabul edilmelidir. Bu nedenle, daha ayrıntılı sonuçlara ulaşmak için gelecek çalışmaların kısmi süreli iş kalitesini cinsiyet, yaş ve eğitim durumu gibi beşeri özellikleri de dikkate alarak, incelemesi bu konudaki bilgi birikimine katkı sağlayacaktır. Ayrıca, bu çalışmada kullanılan iş kalitesi göstergelerinin kısmi süreli istihdam açısından içsel değişken mi, yoksa dışsal değişken mi olduğuna ilişkin bir literatüre rastlanmamıştır. Eğer çalışmada kullanılan değişkenler içsel değişkense, bağımlı değişken ile açıklayıcı değişkenler arasında sonuçların sapmalı ve tutarsız olmasına yol açabilen içsellik (endogenite) sorunu olabilir. Bu açıdan gelecek çalışmaların bu çalışmada kullanılan kısmi süreli istihdam hacmi ile iş kalitesi göstergeleri arasında içsellik sorunu olup olmadığını ekonometrik olarak incelemesi faydalı olacaktır.

\section{Araştırma ve Yayın Etiği Beyanı}

$\mathrm{Bu}$ çalışma bilimsel araştırma ve yayın etiği kurallarına uygun olarak hazırlanmıştır.

\section{Yazarların Makaleye Katkı Oranları}

Yazarın makaleye katkısı \%100’dür.

\section{Çıkar Beyanı}

Yazarlar açısından ya da üçüncü taraflar açısından çalışmadan kaynaklı çıkar çatışması bulunmamaktadır. 


\section{KAYNAKÇA}

Arjona, R, Ladaique, M. ve Pearson, M. (2002). Social Protection and Growth. OECD Economic Studies No. 35, 2002/02. OECD.

Atkinson, J. (1987). Flexibility or fragmentation? The UK labour market in the eighties. Labour and Society, 12(1), $87-105$.

Bardasi, E. ve Gornick, J. C. (2008). Working for less? Women's part-time wage penalties across countries. Feminist Economics, 14(1), 37-72.

Brown, S. H. (2009). Multiple linear regression analysis: A matrix approach with MATLAB Alabama. Journal of Mathematics. Spring/Fall. 1-3.

Campbell, I. ve Chalmers, J. (2008). Job quality and part-time work in the retail industry: An Australian case study. The International Journal of Human Resource Management, 19:3, 487-500, Doi: 10.1080/09585190801895569.

Caputo, R. K. ve Cianni, M., (2001). Correlates of voluntary vs. involuntary part-time employment among US women. Gender, Work and Organization, Vol. 8, No. 3, 311-325.

Cazes, S., A. Hijzen and Saint-Martin A. (2016). Measuring and assessing job auality: The OECD job quality framework. OECD Social, Employment and MigrationWorking Papers, No. 174, OECD Publishing, Paris, http://dx.doi.org/10.1787/5jrp02kjw1mr-en.

Erhel, C. ve Guergoat-Larivière, M. (2010). Job quality and labour market performance. CEPS working Document NO. 330 .

European Commission (2008). Employment in Europe 2008. Luxembourg: Office for Official Publications of the European Communities.

Eurofound (2002). Quality of work and employment in Europe issues and challenges. Foundation Paper N.1. Luxembourg.

Eurofound (2008). Working conditions of an ageing workforce. Luxembourg.

Eurofound (2007). Part-time work in Europe. European Foundation for the Improvement of Living and Working Conditions. [Çevrim-içi: http://www.eurofound.europa.eu/ewco/reports/TN0403TR01/TN0403TR01.pdf], Erişim tarihi: 04.04.2021.

Fagan, C., Norman, H., Smith, M. ve González Menéndez, María C. (2014). In search of good quality part-time employment. International Labour Office, Conditions of Work and Employment Branch. - Geneva: ILO.

Görmüş, A. (2019). Türkiye'de yetersiz istihdam: Cinsiyet temelli bir lojistik regresyon modeli. Çalışma ve Toplum Dergisi, 2019/2(61), 1005-1028.

Görmüş, A. ve Erdoğan Ç. (2017). Türkiye'de gönülsüz kısmi süreli istihdamın cinsiyet analizi: Hane halkı işgücü anketinden bulgular. Balkan Sosyal Bilimler Dergisi, 6, 150-164.

Görgücü, İ. ve Koç, M. (2011). 4857 sayılı iş kanununa göre kısmi çalışma uygulanması. Çalışma ve Toplum Dergisi, 2011/28, 149-174.

Green, F. (2006). Demanding work-the paradox of job quality in the affluent economy. Princeton: Princeton University Press.

Güneş, B. ve Acun, S. (2015). The new instrument of making the labour markets flexible in Turkey: Part-time employment. İ̧̧ Güç, Endüstri Ilişskileri ve Insan Kaynaklarl Dergisi, 17(4). 147-170. Doi: 10.4026/13032860.2015.0302.x

ILO (1999). Decent work. Report of the Director-General. International Labour Conference 87th Session.

ILO (2016). Non-standard employment around the world: Understanding challenges, shaping prospects. International Labour Office. Geneva.

Kalleberg, A., Reskin, B. ve Hudson, K. (2000). Bad jobs in America: Standard and nonstandard employment relations and job quality. American Sociological Review, 65(2), 256-278.

Kalleberg, A. ve Vaisey, S. (2005). Pathways to good job: Perceived job quality among the machinists in North America. British Journal of Industrial Relations, 43(3), 431-454.

Kalleberg, A. (2006). Inequalities of the World. In G. Therborn, G. (Ed.). Non-standard employment relations and Labour Market inequality: Cross-national patterns (pp. 136-161). London, Verso. 
Kauhanen, M. ve Nätti, J. (2015). Involuntary temporary and part-time work, job quality and well-being at work. Social Indicators Research, 120, 783-799. Doi:10.1007/s11205-014-0617-7.

Lucas, R. (1988). On the Mechanics of Economic Development. Journal of Monetary Economics, 22 (1), 3-42.

Mathers, N. ve Slater, R. (2014). Social Protection and Growth: Research Synthesis. Department of Foreign Affairs and Trade, Commonwealth of Australia, Canberra, [Çevrim-içi: https://dfat.gov.au/about-us/publications/Pages/socialprotection-and-growth-researchsynthesis.aspx], Erişim tarihi: 26.05.2021.

McDonald, P., Bradley, L. ve Brown, K. (2009). 'Full-time is a given here': Part-time versus full-time job quality. British Journal of Management, Vol. 20, 143-157. Doi:10.1111/j.1467-8551.2008.00560.

Mutlu, E. (2013). Kısmi süreli çalışmanın iş ve sosyal güvenlik hukuku kapsamında değerlendirilmesi. Sosyal Güvence. (4), 29-49.

OECD (2010). OECD Employment Outlook 2010: Moving Beyond the Jobs Crisis. How good is part-time work? (pp. 211-266). Paris.

OECD (2014). OECD Employment Outlook 2014. OECD Publishing. http://dx.doi.org/10.1787/empl_outlook-2014en.

OECD (2016). How good is your job? Measuring and assessing job quality. OECD Brief. [Çevrim-içi: http://www.oecd.org/sdd/labour-stats/Job-quality-OECD.pdf], Erişim tarihi: 10.03.2021.

OECD (2017). OECD Employment Outlook 2017. OECD Publishing. Paris. http://dx.doi.org/10.1787/empl_outlook2017-en.

OECD (2021). Job quality Stat, 2010-2015. [Çevrim-içi: https://stats.oecd.org/], Erişim tarihi: 12.01.2021.

Stiglitz, J., Sen, A.ve Fitoussi, J.P. (2009). Report by the commission on the measurement of economic performance and social progress, [Çevrim-içi: www.stiglitz-sen-fitoussi.fr/documents/rapport_anglais.pdf], Erişim tarihi: 18.03.2021.

Sungur, O. (2014). Korelasyon Analizi. İçinde: Kalaycı, Ş. (Ed.) SPSS Uygulamalı Çok Değişkenli İstatistik Teknikleri, (ss. 115-127) 6. Baskı, Ankara, Asil Yayın Dağıtım.

Tilly, C. (1996). Half a job: Bad and good part-time jobs in a changing labor market. Philadelphia, PA: Temple University Press.

Tranmer, M., Murphy, J., Elliot, M. ve Pampaka, M. (2020). Multiple linear regression (2nd Edition). Cathie Marsh Institute Working Paper 2020-01. [Çevrim-içi: https://hummedia.manchester.ac.uk/institutes/cmist/archivepublications/working-papers/2020/2020-1-multiple-linear-regression.pdf], Erişim tarihi: 18.03.2021.

Warren, T. ve Lyonette, C. (2015). Unequal Britain at work. In A. Felstead, D. Gallie \& F. Green (Eds.), The Quality of Part-Time Work (pp. 62-82). Oxford University Press.

Warren, T. ve Lyonette, C. (2020). Ungrateful slaves? An examination of job quality and job satisfaction for male part-time workers in the UK. Br. J. Sociol., 71:3, 82-402.

Yalçın, E. C. ve Başol, O. (2020). Kısmi süreli çalışmayı etkileyen bazı sosyo-demografik değişkenler: TR 21 bölgesi örneği. Sosyal Güvenlik Dergisi. 10(1). 75-88. Doi: 10.32331/ sgd.752986.

Yuyucu, A. (2017). Türk iş hukuku çerçevesinde kısmi zamanlı çalışmanın uygulaması. Hak İş Uluslararası Emek ve Toplum Dergisi. 6 (15). 398-407.

Zeytinoğlu, E. (2011). Kısmi süreli çalışma şekilleri ve 4857 sayılı iş kanunundaki görünüm. Journal of Istanbul University Law Faculty. 62 (1-2). 449-466. 
EK. OECD Verileri (2015 veya en güncel yıl)

\begin{tabular}{|c|c|c|c|c|c|c|c|c|}
\hline \multirow[b]{2}{*}{ Ülkeler } & \multirow[b]{2}{*}{ Kisaltma } & \multirow[b]{2}{*}{$\begin{array}{c}\text { Kısmi } \\
\text { Süreli } \\
\text { İstihdam* }\end{array}$} & \multirow[b]{2}{*}{$\begin{array}{l}\text { Kazanç } \\
\text { Kalitesi }\end{array}$} & \multirow[b]{2}{*}{$\begin{array}{c}\text { İşgücü } \\
\text { Piyasası } \\
\text { Güvencesizliği } \\
\end{array}$} & \multicolumn{4}{|c|}{ Çalışma Ortamı Kalitesi } \\
\hline & & & & & $\begin{array}{c}\text { İşs } \\
\text { Zorlanma }\end{array}$ & $\begin{array}{c}\text { Fiziksel } \\
\text { Sağlık Risk } \\
\text { Faktörleri }\end{array}$ & $\begin{array}{l}\text { Eğitim } \\
\text { ve } \\
\text { Öğrenme } \\
\end{array}$ & $\begin{array}{c}\text { Kariyer } \\
\text { İlerleme } \\
\text { Firsatı }\end{array}$ \\
\hline & & $\%$ & $\$$ & $\%$ & $\%$ & $\%$ & $\%$ & $\%$ \\
\hline Avustralya & AUS & 15,01 & 22,68 & 3,37 & 25,57 & 27,22 & 53,45 & 24,92 \\
\hline Avusturya & AUT & 11,82 & 24,26 & 2,06 & 28,52 & 30,85 & 53,94 & 13,22 \\
\hline Belçika & BEL & 9,41 & 31,43 & 2,85 & 25,77 & 28,99 & 61,21 & 12,29 \\
\hline Kanada & CAN & 11,10 & 20,12 & 3,9 & 32,9 & & & \\
\hline Şili & CHL & 4,73 & 6,79 & 6,9 & 28,22 & 26,3 & 41,87 & 33,97 \\
\hline $\begin{array}{l}\text { Çek } \\
\text { Cumhuriyeti }\end{array}$ & CZE & 2,49 & 9,37 & 3,12 & 25,38 & 33,82 & 66,4 & 10,59 \\
\hline Danimarka & DNK & 11,89 & 30,99 & 4,11 & 18,19 & 28,81 & 68,19 & 22,52 \\
\hline Estonya & EST & 5,29 & $8,3^{\mathrm{a}}$ & 5 & 23 & 32,28 & 68,27 & 13,89 \\
\hline Finlandiya & FIN & 7,31 & 21,35 & 2,54 & 16,34 & 34,83 & 71,25 & 14,92 \\
\hline Fransa & FRA & 7,26 & $21,88^{\mathrm{a}}$ & 3,42 & 25,79 & 35,48 & 55,62 & 11,82 \\
\hline Almanya & DEU & 13,03 & 25,73 & 1,67 & 28,53 & 30 & 59,48 & 9,87 \\
\hline Yunanistan & GRC & 5,23 & 9,67 & 22,99 & 47,94 & 30,38 & 28,63 & 7,43 \\
\hline Macaristan & HUN & 2,30 & 7,57 & 5,73 & 36,41 & 31,48 & 33,87 & 16,35 \\
\hline İzlanda & ISL & 13,59 & 20,95 & 1,29 & 23,81 & 25,27 & 57,5 & 31,17 \\
\hline İrlanda & IRL & 13,51 & 17,53 & 3,24 & 23,9 & 28,98 & 71,44 & 18,77 \\
\hline İsrail & ISR & 9,27 & 8,21 & 4,6 & 25,12 & 19,86 & 39,53 & 36,64 \\
\hline İtalya & ITA & 8,57 & $18,85^{\mathrm{a}}$ & 8,23 & 29,59 & 23,34 & 41,99 & 5,46 \\
\hline Japonya & JPN & 13,07 & 17,5 & 2,93 & 31,16 & 19,94 & 46,43 & 8,93 \\
\hline Letonya & LVA & 3,11 & $6,72^{\mathrm{a}}$ & $6,72^{\mathrm{a}}$ & 30,29 & 36,65 & 48,77 & 14,42 \\
\hline Lüksemburg & LUX & 8,00 & $30,54^{\mathrm{a}}$ & 2,21 & 23,06 & 27,42 & 60,34 & 16,31 \\
\hline Meksika & MEX & 6,85 & 4,74 & 4,58 & 28,89 & 24,02 & 42,56 & 39,43 \\
\hline Hollanda & NLD & 23,77 & $28,58^{\mathrm{a}}$ & 3,34 & 23,37 & 24,65 & 64,84 & 16,3 \\
\hline $\begin{array}{l}\text { Yeni } \\
\text { Zelanda }\end{array}$ & NZL & 13,28 & 17,28 & 4,68 & 21,64 & 26,3 & 58,54 & 30,75 \\
\hline Norveç & NOR & 12,43 & 27,77 & 2,91 & 13,83 & 31,81 & 70,33 & 16,18 \\
\hline Polonya & POL & 2,95 & $8,17^{\mathrm{a}}$ & 6,39 & 30,05 & 32,18 & 52,75 & 10,5 \\
\hline Portekiz & PRT & 3,62 & 8,98 & 9,37 & 33,24 & 22,41 & 34,1 & 12,05 \\
\hline $\begin{array}{l}\text { Slovak } \\
\text { Cumhuriyeti }\end{array}$ & SVK & 3,24 & 8,67 & 10,6 & 32,05 & 37,02 & 68,02 & 5,35 \\
\hline İspanya & ESP & 7,11 & $17,45^{\mathrm{a}}$ & 18,53 & 35,01 & 35,64 & 44,77 & 16,48 \\
\hline İsveç & SWE & 8,95 & $20,82^{b}$ & 5,04 & 23,56 & 36,55 & 62,16 & 10,28 \\
\hline İsviçre & CHE & 16,52 & $32,4^{\mathrm{a}}$ & 2,4 & 28 & & & \\
\hline Türkiye & TUR & 1,93 & $7,38^{\mathrm{a}}$ & 11,56 & 42,94 & 32,5 & 28,76 & 27,81 \\
\hline $\begin{array}{l}\text { Birleşik } \\
\text { Krallık }\end{array}$ & GBR & 13,85 & 18,53 & 3,74 & 20,7 & 31,16 & 72,87 & 17,99 \\
\hline ABD & USA & 7,88 & 18,22 & 4,63 & 25,82 & 49,94 & 60,79 & 42,49 \\
\hline OECD Ort. & OECD & 13,02 & 17,46 & 5,6 & 27,65 & 30,12 & 54,6 & 18,24 \\
\hline
\end{tabular}

Kaynak: (OECD Stat, 2021).

* Yazar tarafindan hesaplanmıştır.

a 2014 y1lina ait veri.

b 2013 yllına ait veri. 


\section{Extended Summary}

\section{The Quality of Part-time Jobs: Findings from OECD Countries for Multiple Linear Regression Model}

Part-time work, which is defined as a form of work less than normal working hours, has started to expand as an indicator of the emergence of more flexible and non-standard labour markets since the 1970s (Fagan et al., 2014: 1). In this sense, in many developed countries, it has been an increase in non-standard work arrangements such as part-time work while being a decrease in standard full-time working arrangements on the normative basis of labour relations. This changing in the nature of labour relations has made labour markets and workplaces more flexible (Kalleberg, 2006: 562). However, part-time employment has recently become a current issue with low job quality. This form of employment sometimes leads to greater labour market inequalities while excluding some employees from some social protections offered to them in the standard employment relationship (Kalleberg, 2006: 562). Moreover, it is also admitted that part-time workers are concentrated in poorer working conditions and lower-skilled jobs than full-time workers, and part-time jobs are significantly lower quality than full-time jobs. In this aspect, part-time jobs are associated with lower wages, more limited professional developments, career opportunities and participation in the training, lack of employment protection provided by unions, compared to similar full-time jobs. Therefore, part-time jobs become constantly a focus of criticism as they offer low-quality employment opportunities (Kalleberg et al., 2000: 256-257; Warren \& Lyonette, 2015: 62; OECD, 2010: 221; Fagan et al., 2014: 41).

The economics, sociology and psychology literature show that job quality has deep consequences for the psychological, social and economic well-being of employees. In this respect, social scientists approach job quality research in different ways. For example, economists tend to focus on economic issues, such as wages or health insurance or retirement benefits. Sociologists generally examine the degree of control and autonomy of employees over their jobs and professional prestige in a system of social stratification while psychologists are underlining more on uneconomic aspects of job quality and evaluate the diversity of psychological sources of job satisfaction. Indeed, each of these perspectives is useful, but partially explains job quality. Therefore, understanding job quality requires a multidimensional approach that takes into account economic and non-economic resources related to job quality (Kalleberg and Vaisey, 2005: 431-432). In this sense, different indicators have been developed to measure job quality that contributes to the well-being of the employees and inherently represents by a multidimensional structure. On the one hand, international organizations have developed different approaches on how to measure job quality. For example, the International Labor Organization (ILO) came up with the concept of "decent work" which had been firstly presented at the 87th International Labor Conference in 1999, consisted of four goals in terms of the assessment of job quality: job creation, rights at work, social protection and social dialogue (ILO, 1999: 3-4). On the other hand, the concept of job quality has been on the agenda of the European Union (EU) since 2000. In this sense, in 2001, EU countries were agreed on a broad concept of the job quality known as "Laeken indicators" and measured with 10-dimensional indicators in order to monitor and compare the performances of member states in this field (European Commission, 2008: 153). In addition to these developments, Organisation for Economic Co-operation and Development (OECD) (2014) has developed a "Job Quality Framework" based on the report of the Stiglitz-Sen-Fitoussi Commission (Stiglitz et al., 2009). OECD Job Quality Framework is structured in three main dimensions that measure the wellbeing of employee by nine indicators: earnings quality, labour market insecurity and quality of the working environment. 
Although it is accumulated extensive international literature which has examined the nature of part-time employment and compared the quality of part-time jobs and full-time jobs, it is remarkable the lack of empirical studies on the quality of part-time employment in Turkey. In this sense, it is important and worth to investigate and discuss the quality of part-time employment in terms of widespread in Turkey of part-time employment which is known to have positive effects on women's employment. To contribute to the literature gap and learn the lesson for Turkey, this paper aims to reply to these questions: By which indicators are job quality measured? What is the correlation between job quality and the quantity of part-time employment? Do job quality indicators explain significantly the quantity of part-time employment? To answer these questions and more, this study mainly aims to examine the relationship between the quantity of part-time employment and job quality indicators by correlation and multiple linear regression analysis methods, by using job quality data from OECD countries.

Empirical results present that higher part-time employment rates are related to better job quality. This result implies that there is no necessary trade-off between the quantity of part-time employment and the quality of jobs. Because this relationship is a result that part-time employment rates are relatively higher in developed OECD countries while being relatively lower in developing OECD countries. Despite such a relationship, there are significant differences among countries with similar part-time employment rates in terms of job quality levels. For example, although Mexico and Luxembourg have similar part-time employment rates, earnings quality is higher in Luxembourg. As a result of the correlation analysis, there is a significant correlation with positive direction between the quantity of part-time employment and earnings quality and training and learning while being of a significant correlation with negative direction between the quantity of part-time employment and labour market insecurity, job strain rate and physical health risk factors. Also, regression analysis reveals that the increase in earnings quality, training-learning and opportunity of career advancement as well as the reduction in physical health risk factors may increase the quantity of part-time employment at varying degrees. 